\title{
CREB3L2 wt Allele
}

National Cancer Institute

\section{Source}

National Cancer Institute. CREB3L2 wt Allele. NCI Thesaurus. Code C95481.

Human CREB3L2 wild-type allele is located in the vicinity of 7q34 and is approximately

$127 \mathrm{~kb}$ in length. This allele, which encodes cyclic AMP-responsive element-binding protein 3-like protein 2, plays a role in transcription that occurs in response to endoplasmic reticulum stress. A translocation $\mathrm{t}(7 ; 16)(q 32-34 ; p 11)$ involving the FUS gene and CREB3L2 gene is associated with low-grade fibromyxoid sarcoma. 